\title{
Prevalence of Depression in Pregnant Women with Bariatric Surgery History and Associated Factors
}

\section{Prevalência de depressão em gestantes com histórico de cirurgia bariátrica e fatores associados}

\author{
Andréa Christina Nowak da Rocha ${ }^{10}$ Ana Cristina Barros da Cunha ${ }^{2(0)}$ Jaqueline Ferreira da Silva ${ }^{3(0)}$ \\ ${ }^{1}$ Professional Master's Program in Perinatal Health, Maternidade \\ Escola da UFRJ (ME-UFRJ), Rio de Janeiro, RJ, Brazil \\ 2 Professional Master's Program in Perinatal Health, ME-UFRJ; \\ Postgraduate Program in Psychology, Instituto de Psicologia da

\begin{abstract}
Address for correspondence Andréa Christina Nowak da Rocha, Psychologist, Master's degree, Rua Aires Saldanha, 136/ 704, 22060030, Copacabana, Rio de Janeiro, RJ, Brazil
\end{abstract} \\ (e-mail: andreanowak@hotmail.com).
} UFRJ, Rio de Janeiro, RJ, Brazil

${ }^{3}$ Institute of Psychology, UFRJ, Rio de Janeiro, RJ, Brazil

Rev Bras Ginecol Obstet 2022;44(2):109-117.

\begin{abstract}
Keywords

- bariatric surgery

- pregnancy

- mental health

- depression

- perinatal care

Objective To analyze the prevalence and factors associated with depressive symptoms among Brazilian pregnant women with history of bariatric surgery (BS).

Methods This is a cohort study with 247 women who got pregnant after BS. Based on data collection via Google Form, the recruitment of participants occurred in Facebook groups for 13 months. All of them answered a form with Informed Consent, a general data protocol and the Brazilian version of the Depression, Anxiety and Stress Scale-21. Descriptive and inferential analysis were performed, and a binary logistic regression model was tested to predict the factors associated with depressive symptoms.

Results The prevalence of depressive symptoms was $32.8 \%$, noted as being higher in the first (40.6\%) and third (34.3\%) gestational trimesters. Significative associations were found between depression and marital status $(p=0.000)$, planned pregnancy $(p=0.001)$, desired pregnancy $(p=0.004)$ and psychiatric history $(p=0.000)$. Women who were not married (odds ratio, $\mathrm{OR}=3,38 ; p=0.002$ ) and had a psychiatric history $(\mathrm{OR}=2.70$; $p=0.102$ ) had higher chances of showing depression symptoms; while planned and desired pregnancy showed as protective factors to the symptoms of depression.

Conclusion These findings highlight the importance of psychological assistance for pregnant women with history of BS, to prevent development of mental disorders and their outcomes for maternal-child health.
\end{abstract}

received

December 30, 2020

accepted after revision

October 13, 2021
DOI https://doi.org/

$10.1055 / \mathrm{s}-0042-1742682$. ISSN $0100-7203$ (c) 2022. Federação Brasileira de Ginecologia e Obstetrícia. All rights reserved.

This is an open access article published by Thieme under the terms of the Creative Commons Attribution License, permitting unrestricted use, distribution, and reproduction so long as the original work is properly cited. (https://creativecommons.org/licenses/by/4.0/)

Thieme Revinter Publicações Ltda., Rua do Matoso 170, Rio de Janeiro, RJ, CEP 20270-135, Brazil 


\section{Resumo}

\section{Descritores \\ - cirurgia bariátrica \\ - gravidez \\ - saúde mental \\ - depressão \\ - assistência perinatal}

Objetivo Analisar a prevalência e fatores associados à sintomatologia depressiva entre gestantes brasileiras com histórico de cirurgia bariátrica.

Métodos Trata-se de um estudo de coorte com 247 mulheres que engravidaram após uma Cirurgia Bariátrica. Baseado em coleta via Google Form o recrutamento das gestantes ocorreu em grupos do Facebook durante 13 meses. Todas responderam a um formulário com o Termo de Consentimento Livre e Esclarecido, um protocolo de dados gerais e a versão brasileira da Depression, Anxiety and Stress Scale-21. Análises, descritiva e inferencial foram realizadas, e um modelo de regressão logística binária foi testado para predizer os fatores associados à sintomatologia depressiva.

Resultados A prevalência da sintomatologia depressiva foi de $32,8 \%$, sendo notada como maior no primeiro $(40,6 \%)$ e terceiro $(34,3 \%)$ trimestres gestacionais. Associações significativas foram encontradas entre sintomatologia depressiva e estado civil $(p=0,000)$, gestação planejada $(p=0,001)$, gestação desejada $(p=0,004)$ e histórico psiquiátrico $(p=0,000)$. Mulheres que não eram casadas $(\mathrm{OR}=3,38 ; p=0,002) \mathrm{e}$ tinham um histórico psiquiátrico $(\mathrm{OR}=2,70 ; p=0,102)$ apresentaram mais chances de manifestarem sintomas de depressão; enquanto gestação planejada e desejada mostraram-se como fatores protetivos aos sintomas de depressão.

Conclusão Os achados ressaltam a importância do acompanhamento psicológico para gestantes com histórico de cirurgia bariátrica para prevenção do desenvolvimento de transtornos mentais e seus desfechos para a saúde materno-infantil.

\section{Introduction}

Obesity is a chronic disease which involves genetic, metabolic, behavioral, environmental, cultural, and psychological factors. It is characterized by excess body fat due to energy imbalance for a long period, either by an excessive fat consumption, or by sedentarism or lack of physical activity. ${ }^{1}$ The most recent data of Brazilian's Ministry of Health show that $55.7 \%$ of the Brazilian population is overweight, in other words, closer to obesity. ${ }^{2}$ The rise in obesity in Brazil is justified by the behavioral, social, and dietary transformation of its population. According to Garcia, ${ }^{3}$ the urbanization and industrialization binomial is a predominant factor in the way that people eat, since demand for bad and practical eating, as well as fast foods have increased. This demand makes space for higher consumption of invariable foods, without "real food" that can be found as fast food.

Bariatric surgery (BS) has been embraced as an effective option as a preventive and therapeutic intervention to obesity treatment and its related diseases, such as infertility. ${ }^{4,5}$ In accordance with the $424 / 2013^{4}$ decree of Ministry of Health and the new Brazilian Guidelines of Obesity (2016), ${ }^{5}$ BS candidates must show a body-mass index (BMI) higher than $40 \mathrm{~kg} / \mathrm{m}^{2}$ or $35 \mathrm{~kg} / \mathrm{m}^{2}$, be associated with one or more serious comorbidities caused by obesity, and have attempted, unsuccessfully, non-surgical techniques for losing weight in a prior period of at least two years. ${ }^{4,5}$ The greatest benefit of this surgery procedure is the reduction of comorbidities, although it emphasizes gains with regard to self-esteem, sexuality and social interaction among patients. ${ }^{6}$

In addition to the search for better health conditions, women who underwent BS can also have the urge to conform with a cultural parameter of slimness, in other words, a female physical ideal. However, the fast physical, nutritional, and psychosocial changes which occur after BS, aside from the newest silhouette (excessive or suddenly thin) may cause psychological disorders, such as depression, anxiety, alcoholism, bulimia, and anorexia, as well as other compulsive behaviors/disorders like compulsive gambling, shopping, and hypersexuality. ${ }^{6,7}$

Moreover, it stands out that $80 \%$ of the patients who answered the survey were obese women between 18 and 45years-old. ${ }^{8,9}$ In this population, ovarian polycystic syndrome and infertility are usually found, causing more difficulty to become pregnant. ${ }^{9}$ Studies reveal the weight loss resulting from BS has a positive impact to female fertility, with better obstetric prognosis and reduction of obstetric complications associated with overweight, such as gestational diabetes, hypertension, preeclampsia, thromboembolism, fetal macrosomia, urinary infection, prematurity, intrauterine fetal death, anesthetic, and surgical complications. ${ }^{9,10}$ Nevertheless, women who did BS must be warned about the minimum time to become pregnant after surgery, with the aim to wait for weight stabilization due to deficiency of vitamin, mineral, and protein absorption resulting from digestive physiology changes. ${ }^{6,9}$ This time varies from 12 to 18 months, and it corresponds to a minimum hiatus for a post-BS pregnancy with less maternal-fetal risks. ${ }^{6,9,11}$

Therefore, the risks arising from physical, psychological, and metabolic alterations caused by BS add up to a high vulnerability to mental disorders during the pregnancypuerperal cycle, especially on the first and third trimesters of pregnancy, and on 30 days postpartum (puerperium)..$^{12,13}$ During gestation, this can be explained by issues and fears 
related to the adjustment period to pregnancy and the proximity to childbirth. ${ }^{13,14}$ Besides that, the challenges of the physical and mental transformations related to gestation result in greater emotional ambivalence that must require the women's mental effort to take on a new role as mothers, ${ }^{15}$ which can be harder to women with BS history because of the adaptations in physical and mental levels that result from the surgery.

Despite the emphasis given to puerperal psychological disorders such as postpartum depression, mental disorders during pregnancy are not uncommon and have high prevalence, similar to the puerperal period. ${ }^{16}$ Depressive episodes are the most frequent during gestation ${ }^{12,17}$ and may negatively impact pre- and postnatal care. ${ }^{12}$ Depressive mood or anhedonia is one of main symptoms of depression during pregnancy, albeit alterations in sleep and appetite, irritability, loss of libido, psychomotor retardation, and suicidal ideation are also observed and may cause psychosocial impacts on women. ${ }^{12}$ Thus, some of these manifestations such as fatigue, alterations in sleeping, appetite, and libido patterns may cause misdiagnosis of depression on pregnancy.

Studies reveal that prevalence rates of depression during pregnancy in developing countries, such as Brazil, are around $20 \%{ }^{12,17-20}$ Among risk factors associated with depression during pregnancy the biggest factor seems to be a history of psychiatric conditions, especially depression. ${ }^{12,20}$ Added to that, sociodemographic factors related to poverty, such as unemployment, low income, education, and unwanted pregnancy; and other factors like alcohol dependence and substance abuse, besides lack of social and emotional support are also predictors of depression during pregnancy. ${ }^{14,18-20}$ It is necessary to stress that the presence of untreated depression during pregnancy can lead to fetal-maternal and obstetric risks like the increase of abortion rates, placenta abnormalities, hemorrhage, prematurity, fetal pain, low selfcare, low weight of the newborn, preeclampsia, and low adherence to prenatal monitoring. ${ }^{12,16,21}$ Hence, depression during pregnancy can lead to a higher risk of postnatal depression, has an impact on the mother-child binomial, may compromise the fetal-maternal and mother-child relationship, as well as the child's psychosocial development. ${ }^{18,22,23}$

Thus, the early assessment and treatment of depression symptoms during pregnancy is fundamental to reduce negative outcomes to maternal health, fetal development, labor, and the child's health. ${ }^{12,16}$ Regarding women who underwent $\mathrm{BS}$, there might be higher risks related to psychological disorders in the face of difficulties of adaptation to physical and mental changes resulted from surgery. The purpose of this research is analyze the prevalence of depressive symptomatology in Brazilian pregnant women with history of BS, and study factors associated with depression incidence, as well as predictive factors of depression in this type of pregnancy.

\section{Methods}

This is a quantitative cohort comprised of 247 pregnant women from different Brazilian regions, which fulfilled the following criteria: age equal or superior to 18 years old, pregnant at the moment of the survey, and who underwent BS before getting pregnant. Women who, despite having a history of BS, answered the survey after childbirth were excluded.

The project was approved by the Comitê de Ética em Pesquisa da Maternidade Escola da UFRJ (CAEE: 65713417.9.0000.5275) before the beginning of data collection, which occurred for 13 months, from October 2017 to November 2018. The study was announced on Facebook groups predominantly formed by women who underwent BS and got pregnant or wanted to get pregnant, for example: Pregnancy after Bariatric Surgery, Gestation after Bariatric Surgery and Being a Mother after Bariatric Surgery. After the research was authorized and the researcher was included by group administrators, the participants were invited to the study through a link with access to a survey elaborated in Google Forms. The survey began with an Informed Consent Form (ICF), which was a necessary condition for the participant to proceed and answer the following data collection tools: 1 ) general data protocol for socio demographic, psychosocial and clinical data collection (physical and mental health); 2) Brazilian version of the Depression, Anxiety and Stress Scale (DASS$21)^{24}$ to rate the occurrence of depressive symptomatology detected, with a cutoff point of $\geq 14$, which would correspond to moderate levels of the disorder for DASS- 21 .

All social demographic, psychosocial and clinical data (mental and physical health) were processed and analyzed in terms of frequency of occurrence of information collected by the General Data Protocol. Depressive symptomatology data were rated according to DASS-21 scale's instructions. Analyses, inferential and descriptive, were conducted by using Statistical Package for Social Science (SPSS, IBM Corp. Armonk, NY, USA) version 20.0. The Chi-Squared Test was adopted to investigate sociodemographic (marital status, education, labor activity, and familiar income), psychosocial (planned pregnancy, desired pregnancy, emotional support, financial support, and history of obesity) and clinical factors, as well as both physical health (gestational age and time of BS) and mental health (compulsive behaviors and history of psychiatric disorders) associated with depressive symptomatology, assuming $p$-values $\leq 0.05$ as statistically significant. Finally, a binary logistic regression model was tested to detect predictive factors of depressive symptomatology in pregnant women with history of BS, controlling the following statistically significant variables $(p \leq 0.05)$ : marital status, planned pregnancy, desired pregnancy, and history of psychiatry disorders.

Finally, it is necessary to emphasize that the variables of history of obesity and compulsive behaviors show as missing because they were inserted after the beginning of data collection. Therefore, these two variables were collected only in 71 participants.

\section{Results}

As can be observed on - Table 1, the sample was mostly from married women (84.6\%; $n=209$ ), white women (64.8\%; $n=160$ ), between the age of 30 to 34 -years-old (38.5\%; $\mathrm{n}=95$ ), followed by women from 25 to 29 -years-old 
112 Prevalence of Depression in Pregnant Women with Bariatric Surgery History Nowak da Rocha et al.

(28.3\%; $\mathrm{n}=70$ ). More than a half of them had uncompleted or completed college $(68.9 \% ; \mathrm{n}=124)$. Moreover, $74.5 \%$ ( $\mathrm{n}=184$ ) had labor activities, with monthly incomes centered in the group of 2 to 4 minimum wage $(43.7 \%$; $n=108)$, followed by remunerations between 4 to 10 minimum wage

Table 1 Participants' sociodemographic data $(n=247)$

\begin{tabular}{|c|c|c|c|}
\hline Variables & Category & $\mathbf{n}$ & $\%$ \\
\hline \multirow[t]{3}{*}{ Marital status } & Single & 33 & 13.4 \\
\hline & Married & 209 & 84.6 \\
\hline & Divorced & 5 & 2.0 \\
\hline Total & & 247 & 100 \\
\hline \multirow[t]{5}{*}{ Race/Ethnics } & Yellow & 3 & 1.2 \\
\hline & White & 160 & 64.8 \\
\hline & Mixed race (parda) & 61 & 24.7 \\
\hline & Black & 14 & 5.7 \\
\hline & No answer & 9 & 3.6 \\
\hline Total & & 247 & 100 \\
\hline \multirow[t]{4}{*}{ Age group } & 20 to 24 years & 18 & 7.3 \\
\hline & 30 to 34 years & 95 & 38.5 \\
\hline & 35 to 39 years & 54 & 21.9 \\
\hline & 40 to 44 years & 10 & 4 \\
\hline Total & & 247 & 100 \\
\hline \multirow[t]{4}{*}{ Education } & Incomplete elementary school & 1 & 0.4 \\
\hline & Complete elementary school & 2 & 0.8 \\
\hline & Incomplete middle school & 8 & 3.2 \\
\hline & Complete college & 116 & 47.0 \\
\hline Total & & 247 & 100 \\
\hline \multirow[t]{2}{*}{ Labor Activity } & Yes & 184 & 74.5 \\
\hline & No & 63 & 25.5 \\
\hline Total & & 247 & 100 \\
\hline \multirow[t]{6}{*}{ Family income } & No income & 7 & 2.8 \\
\hline & To 2 minimum wage & 32 & 13.0 \\
\hline & From 2 to 4 minimum wage & 108 & 43.7 \\
\hline & From 4 to 10 minimum wage & 82 & 33.2 \\
\hline & From 10 to 20 minimum wage & 13 & 5.3 \\
\hline & More than 20 minimum wage & 5 & 2.0 \\
\hline Total & & 247 & 100 \\
\hline \multirow[t]{5}{*}{ Brazilian region } & North & 2 & 0.8 \\
\hline & Northeast & 33 & 13.4 \\
\hline & Center-West & 16 & 6.5 \\
\hline & Southeast & 132 & 53.4 \\
\hline & South & 64 & 25.9 \\
\hline Total & & 247 & 100 \\
\hline \multirow[t]{3}{*}{ Prenatal assistance } & Public institution & 50 & 20.2 \\
\hline & Private institution & 188 & 76.1 \\
\hline & No monitoring & 9 & 3.6 \\
\hline Total & & 247 & 100 \\
\hline
\end{tabular}

(33.2\%; $\mathrm{n}=82$ ). In the most part, participants lived in the Southeast of Brazil (53.4\%; $n=132)$, and $79.1 \%(n=188)$ of them did prenatal in the private health care system.

In relation to psychosocial data, though half of the women $(51 \% ; n=126)$ declared unplanned pregnancy, it is understood that gestation was predominantly desired by them (86.6\%; $n=214)$. Nonetheless, 56.3\% $(n=139)$ denied having financial and/or emotional support, $37.7 \%(n=93)$ reported having emotional support, and 3.2\% $(n=8)$ both supports. Most of the women declared being obese since childhood (42.3\%; $n=30$ ), followed by adolescence (36.6\%; $n=26$ ).

Clinical data of mental and physical health are described in -Table 2. It is noted that $25.9 \%(n=64)$ were found in the first gestational trimester, $34 \%(n=84)$ in the second trimester, and $40.1 \%(n=99)$ in the third trimester. Most participants declared being pregnant after 18 months of BS (63.6\%; $\mathrm{n}=157$ ) by Gastric Bypass technique (87.4\%; $\mathrm{n}=216)$, and are still on medical follow-up (47.4\%; $n=117)$. Most of them (78.9\%) reported having some disease before pregnancy, with clinical pathologies such as systemic arterial hypertension, anemia, hypothyroidism, diabetes, musculoskeletal disorders, and hepatic steatosis in more than half of them (53.4\%; $\mathrm{n}=132$ ); followed by history of psychiatric disorders, such as depression and anxiety/panic attack (12.1\%; $\mathrm{n}=30)$, or both (13.4\%; $n=33)$.

Based on the Diagnostic and Statistical Manual of Mental Disorders (DSM-5) ${ }^{25}$ diagnostic criteria: $39.4 \%(n=28)$ of the women declared having compulsive behaviors during pregnancy, with $32.4 \%(\mathrm{n}=23)$ being eating compulsions such as bulimia nervosa (11.3\%; $\mathrm{n}=8$ ), anorexia nervosa $(2.8 \%$; $\mathrm{n}=2)$, and binge eating disorder $(18.3 \% ; \mathrm{n}=13)$.

The estimated prevalence of gestational depressive symptomatology of women with history of BS on this survey was of $32.8 \%(\mathrm{M}=11.4 ; \mathrm{DP}=11.5 ; \mathrm{AV}=0-42)$, with a cutoff point of $\geq 14$, which is considered moderate depressive symptomatology level by DASS-21.

On - Table 3 were presented the Chi-Squared Test results used to test relations among depressive symptomatology in pregnant women and sociodemographic, psychosocial, and clinical variables. Variables such as marital status $(p=0.000)$, planned pregnancy $(p=0.001)$, wanted pregnancy $(p=0.004)$, and history of psychiatric disorders $(p=0.000)$ showed statistically significant association with depressive symptoms ( $p \leq 0.05$ ). Then, unmarried women, who did not plan or want the pregnancy, and had a history of psychiatric disorders (depression, anxiety, and/or panic attack) had high depressive symptomatology scores identified by DASS- 21 . Other variables such as education, income, social and emotional support, gestational age, labor activity, history of obesity, time of BS before getting pregnant, gestational trimester, and compulsive behaviors do not show a statistically significant association with depressive scores.

The result of binary logistic regression was significative: $\mathrm{X}^{2}(5)=276.759 ; p<0.001 ; \mathrm{R}^{2}$ Nagelkerke $=0.188$, and confirmed that variables like marital status and history of psychiatric disorders were predictors of depressive symptomatology's occurrence in the pregnant women with history of BS participants in this survey. As noted in - Table 4, single 
Table 2 Clinical data about participants' physical and mental health $(n=247)$

\begin{tabular}{|c|c|c|}
\hline Indicators of clinical health & Frequency & $\%$ \\
\hline \multicolumn{3}{|l|}{ Gestational age } \\
\hline 1 to 13 weeks ( $1^{\text {st }}$ Trimester) & 64 & 25.9 \\
\hline 14 to 26 weeks ( $2^{\text {nd }}$ Trimester) & 84 & 34.0 \\
\hline 27 to 40 weeks ( $3^{\text {rd }}$ Trimester) & 99 & 40.1 \\
\hline Total & 247 & 100 \\
\hline \multicolumn{3}{|l|}{ Time of BS } \\
\hline Less than 6 months & 7 & 2.8 \\
\hline 6 to 11 months and 30 days & 28 & 11.3 \\
\hline 12 to 17 months and 30 days & 55 & 22.3 \\
\hline 18 months to 23 months and 30 days & 35 & 14.2 \\
\hline More than 24 months & 122 & 49.4 \\
\hline Total & 247 & 100 \\
\hline \multicolumn{3}{|l|}{ Type of BS } \\
\hline Gastric bypass & 216 & 87.4 \\
\hline Vertical gastrectomy & 31 & 12.6 \\
\hline Total & 247 & 100 \\
\hline \multicolumn{3}{|l|}{ Time of medical supervisor after BS } \\
\hline Less than 6 months & 25 & 10.1 \\
\hline 6 months to 1 years & 52 & 21.1 \\
\hline 1 year to 2 years & 53 & 21.5 \\
\hline Still on supervisor & 117 & 47.4 \\
\hline Total & 247 & 100 \\
\hline \multicolumn{3}{|l|}{ Diseases before pregnancy } \\
\hline Clinical pathologies & 132 & 53.4 \\
\hline History of psychiatric disorders & 30 & 12.1 \\
\hline Both & 33 & 13.4 \\
\hline None & 52 & 21.1 \\
\hline Total & 247 & 100 \\
\hline \multicolumn{3}{|l|}{ Compulsive behaviors } \\
\hline Bulimia nervosa & 8 & 11.3 \\
\hline Anorexia nervosa & 2 & 2.8 \\
\hline Binge eating disorder & 13 & 18.3 \\
\hline Alcohol use disorder & 2 & 2.8 \\
\hline $\begin{array}{l}\text { Disorder related to substance abuse } \\
\text { (sedatives, hypnotics, anxiolytics or drugs) }\end{array}$ & 1 & 1.4 \\
\hline $\begin{array}{l}\text { Other compulsions } \\
\text { (sex, gambling, physical exercise, } \\
\text { shopping etc.) }\end{array}$ & 2 & 2.8 \\
\hline No & 43 & 60.6 \\
\hline Total & 71 & 100 \\
\hline Didn't answer & 176 & 0 \\
\hline
\end{tabular}

Abbreviations: BS, bariatric surgery.

women with history of $\mathrm{BS}$ proved to be three times $(\mathrm{OR}=3.38$; $95 \% \mathrm{CI}=1.586-7.221 ; p=0.002$ ) more likely to develop depressive symptoms, when compared to married women. Similarly, pregnant women with history of psychiatric disorders showed a more than double chance $(\mathrm{OR}=2.70 ; 95 \% \mathrm{CI}$ $=1.438-5.081 ; p=0.102$ ) to develop these symptoms.

In contrast, planned pregnancy $(p=0.102)$ and desired pregnancy $(p=0.438)$, do not perform as significance predictions to depression occurrence in this population. On the contrary, planned pregnancy $(\beta=-0.530 ; O R=0.59)$ and desired pregnancy $(\beta=-0.592 ; \mathrm{OR}=0.55)$ may represent protection factors to this population, since in these cases participants had nearly 40\% (41 and 45\%, respectively) less probability of having depressive symptoms.

\section{Discussion}

In order to investigate the prevalence and related factors to depressive symptomatology in pregnant women with history of BS, this study shows scientific evidence about the importance of examining depressive symptoms in this population. In accordance with the expected results, women who underwent BS are more likely to have mental disorders during the pregnancy-puerperal cycle, especially in the first and third trimesters of pregnancy. Our results confirmed that the prevalence of depressive symptomatology (32.8\%) among pregnant women who underwent BS is higher than in low-risk pregnant women, which is around $20 \%{ }^{12,17,18,20}$ Marital status, planned and desired pregnancy, and history of psychiatric disorders are factors that must be considered in prenatal monitoring of this population because they are significantly related to depressive symptoms.

Moreover, it should be noted that this study would be done on newly released Endocrine Technological Disorders Unit in Pregnancy (Unidade de Transtornos Endócrino-Metabólicos na Gestação - UTEM) at the Maternity School of Federal University of Rio de Janeiro, a public service reference center to perinatal health essential care in Rio de Janeiro, Brazil. However, participants' recruitment to the survey in this unit was not possible, bearing in mind the low demand for this service. It must be observed that the adherence of the pregnant population with BS history to public services specialized in gestational health was not frequent. In Rio de Janeiro, in addition to UTEM, only the Public Servants Federal Hospital of the State (Hospital Federal dos Servidores do Estado) offers public prenatal monitoring oriented to post-bariatric pregnant women. In other words, the women who did their prenatal on those services, which mostly focused on low-risk and typical pregnancies, did not receive the necessary care oriented to their characteristics.

Although public health policies in Brazil assure BS indication in cases of severe obesity, like class III, ${ }^{26}$ to be adopted, an as a procedure to infertility treatment among women, ${ }^{27}$ it was observed that a large part of them sough care in private institutions, where it is not always possible to guarantee a multiprofessional, specialized service, capable of caring for and reducing risks in a pregnancy post-BS. It should also be stressed that UTEM is a unit which aims to create a multiprofessional model of prenatal service to the pregnant population with different types of endocrine metabolic disorders, such as obesity, diabetes, and history of BS. The specialized service to this type of pregnancy is important, due to the 
114 Prevalence of Depression in Pregnant Women with Bariatric Surgery History Nowak da Rocha et al.

Table 3 Data of the relation among depressive symptomatology and participants' sociodemographic, psychosocial and clinical variables $(n=247)$

\begin{tabular}{|c|c|c|c|c|c|}
\hline \multirow[t]{2}{*}{ Variables } & \multicolumn{2}{|c|}{$\begin{array}{l}\text { No depressive } \\
\text { symptoms }\end{array}$} & \multicolumn{2}{|c|}{$\begin{array}{l}\text { With depressive } \\
\text { symptomatology }\end{array}$} & \multirow[b]{2}{*}{$P$-value } \\
\hline & $\mathbf{n}$ & $\%$ & $\mathbf{n}$ & $\%$ & \\
\hline Marital status & & & & & $0.000^{*}$ \\
\hline Unmarried & 16 & 41 & 23 & 16 & \\
\hline Married & 150 & 72.1 & 58 & 150 & \\
\hline Education & & & & & 0.062 \\
\hline Completed and uncompleted elementary school & 3 & 100 & 0 & 0 & \\
\hline Completed and uncompleted high school & 56 & 75.7 & 18 & 24.3 & \\
\hline Completed and uncompleted college & 107 & 66 & 55 & 34 & \\
\hline Family income & & & & & 0.096 \\
\hline No income & 4 & 57.1 & 3 & 42.9 & \\
\hline Up to 2 minimum wage & 17 & 53.1 & 15 & 46.9 & \\
\hline From 2 to 4 minimum wage & 79 & 73.1 & 29 & 26.9 & \\
\hline From 4 to 10 minimum wage & 52 & 63.4 & 30 & 36.6 & \\
\hline From 10 to 20 minimum wage & 10 & 76.9 & 3 & 23.1 & \\
\hline More than 20 minimum wage & 4 & 80 & 1 & 20 & \\
\hline Labor activity & & & & & 0.177 \\
\hline Yes & 150 & 71.1 & 58 & 28.9 & \\
\hline No & 16 & 41 & 23 & 59 & \\
\hline Planned pregnancy & & & & & $0.001^{* *}$ \\
\hline Yes & 96 & 77.4 & 28 & 96 & \\
\hline No & 70 & 56.9 & 53 & 70 & \\
\hline Desired pregnancy & & & & & $0.004^{*}$ \\
\hline Yes & 151 & 70.6 & 63 & 29.4 & \\
\hline No & 15 & 45.5 & 18 & 54.5 & \\
\hline Emotional support & & & & & 0.605 \\
\hline Yes & 66 & 65.3 & 35 & 34.7 & \\
\hline No & 100 & 68.5 & 46 & 31.5 & \\
\hline Financial support & & & & & 0.238 \\
\hline Yes & 8 & 53.3 & 7 & 46.7 & \\
\hline No & 158 & 68.1 & 74 & 31.9 & \\
\hline History of obesity & & & & & 0.974 \\
\hline Obese since childhood & 21 & 70 & 9 & 30 & \\
\hline Obese as of adolescence & 18 & 69.2 & 8 & 30.8 & \\
\hline Obese as of adulthood & 10 & 66.7 & 5 & 33.3 & \\
\hline Gestational age & & & & & 0.122 \\
\hline $1^{\text {st }}$ Trimester & 38 & 59.4 & 26 & 40.6 & \\
\hline $2^{\text {nd }}$ Trimester & 63 & 75 & 21 & 25 & \\
\hline $3^{\text {rd }}$ Trimester & 65 & 65.7 & 34 & 34.3 & \\
\hline History of psychiatric disorders & & & & & $0.000^{*}$ \\
\hline Yes & 31 & 49.2 & 32 & 50.8 & \\
\hline No & 45 & 86.5 & 7 & 13.5 & \\
\hline Compulsive behaviors & & & & & 0.197 \\
\hline Eating disorder & 11 & 52.4 & 10 & 47.6 & \\
\hline Disorder related to use of some substance & 2 & 66.7 & 1 & 33.3 & \\
\hline Other compulsions & 1 & 50 & 1 & 50 & \\
\hline No & 35 & 77.8 & 10 & 22.2 & \\
\hline
\end{tabular}

Notes: (\%) frequency; ${ }^{*} p \leq 0,05 ;{ }^{* *}$ with $p \leq 0,001$ being statistically significant. 
Table 4 Predictive factors of depressive symptomatology in participants ( $n=247$ )

\begin{tabular}{lllll}
\hline Variables & $\beta$ & OR & $95 \% \mathrm{Cl}$ & $P$-value \\
\hline Marital status & 1.219 & 3.38 & $1.586-7,221$ & $0.002^{* *}$ \\
Planned pregnancy & -0.530 & 0.59 & $0.312-1,111$ & 0.102 \\
Wanted pregnancy & -0.592 & 0.55 & $0.234-1,305$ & 0.438 \\
History of & 0.994 & 2.70 & $1.438-5,081$ & $0.002^{* *}$ \\
psychiatry disorder & & & & \\
\hline
\end{tabular}

Abbreviations: $95 \% \mathrm{Cl}, 95 \%$ confidence interval; OR, odds ratio. Notes: ${ }^{*} p \leq 0,05$; ${ }^{* *}$ with $p \leq 0,001$ being statistically significant.

demand for attention directed to the related risk factors related to gestation after BS, whose impacts to the mother-child binomial are unquestionable. Studies reveal that these risks have different negative results for the mother, such as nutrient deficiency, ${ }^{28}$ that may cause anemia, malnutrition, and intestinal obstruction. ${ }^{28}$ And for fetal development, it is observed a higher incidence of congenital anomalies, such as neural tube defect and intrauterine growth restriction, ${ }^{29}$ and the consequences to the child's health in their development, such as premature birth and low birth weight. ${ }^{29}$

Due to the struggle to gather face-to-face data from UTEM patients, the survey's data collection happened, exclusively, in an online environment. This can, for instance, explain the participants' high level of education. Therefore, the participants were recruited in Facebook groups related to women who got pregnant and/or wanted to get pregnant after BS. In these groups they share their experiences before, during, and after gestation. In this virtual context, we observed that pregnant women seem to adopt various methods to deal with difficulties related to maternity, creating support networks and closer ties with other women in these groups. According to Frossard and Dias, ${ }^{30}$ internet groups facilitate communication among peers and enable the gathering, organization, and circulation of information about people's needs, and focus on respective demands. In the groups where the survey was made, a huge circulation of information about various aspects involving a gestation after BS was noted. In the vast majority, the information was practical in nature, without a scientific accuracy and without any commitment to medical discourse. Still, it was possible to note that the participants, for the most part, followed medical advice because they kept up medical monitoring (79.1\%) and got pregnant after 18 months of BS (63.3\%), which is the minimum period recommended for a low-risk pregnancy $6,9,11$ after BS by surgical technique gastric bypass (87.4\%), which is, according to Santo et al., ${ }^{9}$ the golden pattern to this type of obesity treatment.

Since the research's proposal was to recognize indicators of mental health, more specifically of mood disorders, in pregnant women after BS, we chose to call it "depressive symptomatology" and not "depression", as depression is a psychopathological disorder which demands wider psychiatric and psychodiagnostic assessments. Likewise, DASS-21 is a scale with good psychometric properties to depression symptoms' measurement in Brazilian population. ${ }^{24}$ Although this scale is not validated for use in the pregnant population yet, some cautions were adopted to minimize this limitation of the instrument. To identify pregnant women with depressive symptomatology, higher cutoff points were chosen. Different from cutoff $<9$, that indicates there are no depression symptoms in the population in general, the chosen cutoff point was $\geq 14$, which would indicate the presence of moderate symptoms in the patients. Here, we clarify that this decision was adopted after doing analyses using two cutoff points: $\geq 10$, which identifies mild symptoms, and $\geq 14$, for moderate symptoms. the first cutoff found a prevalence of $46.9 \%$, which is higher than the prevalence of depression among low-risk pregnant women (20\%). ${ }^{12,17,18,20}$ Therefore, the cutoff $\geq 14$ would be more indicated to investigate the presence of depression symptoms in the population observed, even without a support of DASS-21's psychometric study of sensitivity and specificity for use in pregnant women.

Thus, it is important to discuss how the prevalence of $32.8 \%$ depressive symptomatology in pregnant women after BS was higher when compared to that in low-risk pregnant women. ${ }^{12,17,18}$ Depression symptoms were more frequent in the first (40.6\%) and third trimesters (34.3\%), which reinforces the need for policies focused on pregnancy health in the most critical moments during gestation, either by issues related to pregnancy adaptation or to the fear of childbirth. ${ }^{13,14}$ This response reinforces the idea that gestation is, indeed, a difficult and vulnerable time in a woman's life which can lead to psychiatric disorders $^{12,13}$ particularly associated with physical, hormonal, mental, and social changes, specific from this period. 8,16

Regarding the support system, although most of the participants were married (84.6\%), 56.3\% denied having any type of financial and/or emotional support. Our data indicates that single women with history of BS showed three times more chances $(\mathrm{OR}=3.38 ; 95 \% \mathrm{CI}=1.586-7.221 ; p=0.002)$ to manifest depressive symptoms, when compared with married women, which highlights the importance of support systems (emotional and social) to face the issues and insecurities that the pregnancy-puerperal period can bring.

Likewise, the presence of psychiatric history (anxiety, panic attack, and depression) found in $25.5 \%$ of the participants must be considered, since psychiatric disorders previous to pregnancy may have obstetric, neonatal, and puerperal impacts. The increase of abortion rates, ${ }^{12,16,18}$ hemorrage, ${ }^{12,16,18}$ low birth weight, ${ }^{12,16,18}$ and the consequences to psychosocial child development, ${ }^{12,16,18}$ are examples of negative outcomes to the mother-child binomial related with these disorders during the pregnancy-puerperal cycle. Moreover, psychiatric backgrounds may result in a lesser adherence to prenatal care, ${ }^{12,16,18}$ with difficulties for the woman to adopt selfcare habits, ${ }^{16,18}$ impacts to the quality of the maternal-fetal 
relationship during pregnancy, and the mother-child relationship on puerperium, especially for its association with postnatal depression. ${ }^{12,16,18}$ Ratified these risks, we verified that the participants with psychiatric backgrounds demonstrate double chances $(\mathrm{OR}=2.70 ; 95 \% \mathrm{CI}=1.438-5.081)$ of manifesting depression symptoms on gestation after BS.

These findings deserve attention because $39.4 \%$ of the participants also report compulsive behaviors, especially disorders related to eating, such as binge eating disorder (18.3\%), bulimia nervosa (11.3\%), and anorexia nervosa (2.8\%). Studies suggest these behaviors are common in patients with history of $\mathrm{BS}^{6,7,29,31,32}$ and may indicate the destination of voracity, despair, and eating impulse $\mathrm{s}^{31,32}$ in these pregnant women. Paradoxically, these behaviors were not related to depressive symptomatology in the participants of this study. Although BS has weight loss as objective, as well as mental and physical health improvement, the presence and/or conservation of compulsive behaviors in pregnant women seem to work as a strategy to relieve their anguish, with effects on mood responses such as depression during pregnancy. We may assume that compulsive behaviors involved in this period can be moderators of the anxiety typical during pregnancy, and high prevalence of depressive symptomatology during pregnancy after BS.

Despite the improvement of metabolic and reproductive functioning after the surgery procedure, ${ }^{5,9,11}$ the decision to do a BS does not seem to be a determinant to the intent of getting pregnant, as there was no significative difference between the women who planned (49\%) and those who did not (51\%) their pregnancies. Nevertheless, most of them $(86.6 \%)$ affirmed that the gestation was desired. It should be reinforced that neither planned pregnancy $(\beta=-0.53 ; \mathrm{OR}=0.58 ; p=0.102)$ nor desired pregnancy $(\beta=-0.59 ; \mathrm{OR}=0.55 ; p=0,438)$ were predictive factors for depressive symptoms. On the contrary, these factors appear as protectives to the occurrence of depression symptoms for this population, since women who planned and wanted to get pregnant had around 40\% (41 and 44\% respectively) less chances to manifest those symptoms. This suggests that pregnancy planning and willingness are protective factors to the mental health of pregnant people with a history of BS.

Most of the women affirmed that they were obese since childhood (42.3\%) or adolescence (36.6\%). Although there is no significative association with depression indicators, we may infer that, despite weight gain before pregnancy, the pressure for a perfect body reduces during gestation due to the expected physical transformations ${ }^{28}$ and, possibly, there is a sort of social tolerance for the pregnant body to be a nonstandard body imposed by thinness culture. In spite of that, although gestational age is not associated significantly with depression symptoms, these symptoms were more frequent in pregnant women in the first $(40.6 \% ; \mathrm{n}=26)$ and third trimesters $(34.3 \%$; $\mathrm{n}=34$ ). It seems to indicate that, as literature has already considered, there is a variation between risks for mental disorders during the pregnancy-puerperal cycle, ${ }^{12,13}$ when the second trimester is a moment of emotional stability. Presumably, the difficulties during the adaptation to physical, mental, and social transformations, typical from pregnancy after BS, may result in a higher emotional ambivalence that require women's mental efforts to take a new role as mother. ${ }^{15}$ And, still, it seems that due to the physical transformations during gestational trimesters, with the changes of a pregnant body and the alterations of body image, women are more vulnerable to the manifestation of depressive symptomatology, even if it is not significantly related to history of obesity.

Finally, some limitations of this study must be indicated. First, while online collection via Facebook groups enabled this research and expanded its reach, by recruiting participants from different parts of Brazil, the lack of face-to-face meetings between researcher and participants may have caused difficulties to clarify doubts about the survey. Although this strategy of online survey is becoming more disseminated, especially during the Coronavirus pandemic, this type of data collection precludes capture of nuances which face-toface collection of data may generate, although the participants might feel more comfortable answering the study online. A second important limitation involves the DASS-21 scale used to identify participants with depression symptoms. We reinforce that although it might be a limitation to this study, the choice of DASS-21 was due to it being an easy instrument of application and analysis, besides having a user-friendly language, mainly by collecting data in a virtual environment. For this reason, the studies suggest we use more tools with the purpose of expanding scientific knowledge and the recognition of risk factors and protection related to this type of gestation.

In conclusion, the evaluation of possible mental disorders during pregnancy with history of BS is fundamental, since identifying the risk factors and protections associated with these cases would allow the medical staff to plan specific and preventive interventions for the negative outcomes that this condition imposes. The discoveries in this study ratify the importance of early tracking, diagnostic, and treatment to reduce the impact of perinatal mental disorders, both for the mother and child's health. ${ }^{12,20}$

\section{Conclusion}

Therefore, we concluded that the prevalence of depressive symptomatology in pregnant women with BS is higher than what was found in low-risk pregnancies, proving the psychological control of these women is related to prenatal factors, since this condition may show impacts to the mother-child binomial with short, medium and long-term outcomes. Some factors, such as marital status, planned pregnancy, desired pregnancy, and psychiatric history must be observed by the professionals involved. Henceforth, it is necessary to emphasize that planned and desired pregnancies seem to succeed as protection factors to depressive symptomatology, even if these topics were poorly studied into the perinatal psychology field. Considering obstetric mental disorders, serious consequences to fetal-maternal health, and the underdiagnosis of these disorders in this period, the results of this research indicate the importance of psychological support to pregnant women who underwent BS. Moreover, the training of multiprofessional teams is fundamental for the early recognition and strategic orientation for pregnant women with some symptoms of those disorders, for the sake of a better psychodiagnostic assessment 
and appropriate treatment, minimizing the negative impacts on obstetric and neonatal care. This study highlights the importance of new studies about depression in pregnancy, so that they can subsidize clinical eye development, sensitive and wide, which is oriented to subjective questions from pregnant women with BS, bearing in mind a total attention to perinatal health care of these women and their families.

\section{Contributors}

All authors were involved in the design and interpretation of the analyses, contributed to the writing of the manuscript, read and approved the final manuscript.

\section{Conflict of Interests:}

The authors have no conflict of interests to declare.

\section{References}

1 Obesity: preventing and managing the global epidemic. Report of a WHO consultation. World Health Organ Tech Rep Ser. 2000; 894i-xii, 1-253

2 Ministério da Saúde. Secretaria de Vigilância em Saúde. Departamento de Análise em Saúde e Vigilância de Doenças Não Transmissíveis. Vigitel Brasil 2018: vigilância de fatores de risco e proteção para doenças crônicas por inquérito telefônico: estimativas sobre frequência e distribuição sociodemográfica de fatores de risco e proteção para doenças crônicas nas capitais dos 26 estados brasileiros e no Distrito Federal em 2018. Brasília (DF): Ministério da Saúde; 2019

3 Diez Garcia RW. Reflexos da globalização na cultura alimentar: considerações sobre as mudanças na alimentação urbana. Rev Nutr. 2003;16(04):483-492. Doi: 10.1590/S1415-52732003000400011

4 Ministério da Saúde. Portaria No. 424, de 19 de março de 2013. Redefine as diretrizes para a organização da prevenção e do tratamento do sobrepeso e obesidade como linha de cuidado prioritária da Rede de Atenção à Saúde das Pessoas com Doenças Crônicas. Diário Oficial da União. Seç.. 2013;1:23-24

5 Associação Brasileira para o Estudo da Obesidade e da Síndrome Metabólica. Diretrizes brasileiras de obesidade. 4a ed. São Paulo: ABESO; 2016

6 Sacramento LS, Ferraz LG, Rodrigues AS. Atenção à saúde da gestante pós-cirurgia bariátrica. Rev Eletrônica Estácio Saúde [Internet]. 2013 [cited 2020 Nov 1];2(02):47-60http://revistaadmmade.estacio.br/index.-

php/saudesantacatarina/article/view/639/339

7 Langaro F, Vieira AP, Poggere LC, Trentini CM. Características de personalidade de mulheres que se submeteram à cirurgia bariátrica. Aval Psicol. 2011;10(01):71-79http://pepsic.bvsalud. org/pdf/avp/v10n1/v10n1a08.pdf

8 Nascimento CA, Bezerra SM, Angelim EM. Vivência da obesidade e do emagrecimento em mulheres submetidas à cirurgia bariátrica. Estud Psicol (Natal) [Internet]. 2013 [cited 2020 Nov 10];18(2):193-201. Available from: https://www.scielo.br/pdf/epsic/v18n2/v18n2a04.pdf 9 Santo MA, Riccioppo D, Cecconello I. Tratamento cirúrgico da obesidade mórbida implicações gestacionais. Rev Assoc Med Bras (1992). 2010;56(06):616-619. Doi: 10.1590/S0104-42302010000600001

10 Melo FLE, Melo M. Impacto da cirurgia bariátrica na fertilidade feminina: revisão. Reprod Clim.. 2017;32(01):57-62. Doi: 10.1016/ j.recli.2017.04.001

11 Ilias EJ. Considerações sobre gravidez após cirurgia bariátrica: evidências atuais e recomendações. Rev Assoc Med Bras. 2008;54 (06):475. Doi: 10.1590/S0104-42302008000600003

12 Ministério da Saúde. Secretaria de Atenção à Saúde. Departamento de Ações Programáticas Estratégicas. Gestação de alto risco: manual técnico. 5a ed. Brasília (DF): Ministério da Saúde; 2012. (Série A. Normas e manuais técnicos)
13 Botega NJ, Dias MK. Gravidez e puerpério. In: Botega NJ, ed. Organizador. Prática psiquiátrica no hospital geral: interconsulta e emergência. 2a ed. Porto Alegre: Artmed; 2006:341-54

14 Rodrigues OM, Schiavo RdeA. [Stress in pregnancy and puerperium: a correlation with postpartum depression]. Rev Bras Ginecol Obstet. 2011;33(09):252-257. Doi: 10.1590/S010072032011000900006 Portuguese.

15 Szejer M, Stewart R. Nove meses na vida da mulher: uma abordagem psicanalítica da gravidez e do nascimento. São Paulo: Casa do Psicólogo; 1997

16 Camacho RS, Cantinelli FS, Ribeiro CS, Cantilino A, Gonsales BK, Braguittoni E, et al. Transtornos psiquiátricos na gestação e no puerpério: classificação, diagnóstico e tratamento. Rev Psiq Clin (Santiago). 2006;33(02):92-102. Doi: 10.1590/S0101-60832006000 200009

17 Bennett HA, Einarson A, Taddio A, Koren G, Einarson TR. Prevalence of depression during pregnancy: systematic review. Obstet Gynecol. 2004;103(04):698-709. Doi: 10.1097/01. AOG.0000116689.75396.5f

18 Pereira PK, Lovisi GM. Prevalência da depressão gestacional e fatores associados. Rev Clin Psiquiatr (Santiago). 2008;35(04): 144-153. Doi: 10.1590/S0101-60832008000400004

19 Kliemann A. Sintomas depressivos na gestação: fatores de risco e de proteção em gestantes de alto risco [dissertação]. Florianópolis: Universidade Federal de Santa Catarina; 2017

20 Almeida MS, Nunes MA, Camey S, Pinheiro AP, Schmidt MI. Transtornos mentais em uma amostra de gestantes da rede de atenção básica de saúde no Sul do Brasil. Cad Saude Publica. 2012; 28(02):385-393. Doi: 10.1590/S0102-311X2012000200017

21 Lopes RS, Lucchese R, Silva GC, Vera I, Souza LM, Mendonça RS. Período gestacional e transtornos mentais: evidências epidemiológicas. Humanidad Tecnol Rev.. 2019;19(01):35-54

22 Costa DO, Souza FI, Pedroso GC, Strufaldi MW. Transtornos mentais na gravidez e condições do recém-nascido: estudo longitudinal com gestantes assistidas na atenção básica. Ciênc Saúde Coletiva. 2018; 23(03):691-700. Doi: 10.1590/1413-81232018233.27772015

23 Krob AD, Godoy J, Leite KP, Mori SG. Depressão na gestação e no pós-parto e a responsividade materna nesse contexto. Rev Psicol Saúde. 2017;9(03):3-16. Doi: 10.20435/pssa.v9i3.565

24 Vignola RC, Tucci AM. Adaptation and validation of the depression, anxiety and stress scale (DASS) to Brazilian Portuguese. J Affect Disord. 2014;155:104-109. Doi: 10.1016/j.jad.2013.10.031

25 American Psychiatry Association. Diagnostic and Statistical Manual of Mental Disorders: DSM-5. 5th ed. Washington (DC): American Psychiatric Association; 2013

26 Cairolli PB. Avaliação da imagem corporal e da (in) satisfação com o corpo gravídico pela escala de medida em imagem corporal em gestantes inscritas no programa de pré-natal da rede básica de saúde de Vinhedo [dissertação]. São Paulo: Universidade Estadual de Campinas; 2009

27 Gregório JA. Aspectos nutricionais após cirurgia bariátrica: da gestação ao nascimento [Trabalho de Conclusão de Curso]. Brasília (DF): Universidade de Brasília; 2016

28 Coelho A, Braga A, Nunes I, Cardoso G, Gonçalves H, Marques I, et al. Gravidez após cirurgia bariátrica. Acta Obstet Ginecol Port. 2020;14(02):106-110

29 Araújo GB, Brito AP, Mainardi CR, Martins Neto ES, Centeno DM, Brito MV. Perfil clínico-epidemiológico de pacientes submetidos à cirurgia bariátrica. Pará Res Med J.. 2018;1(04):e38. Doi: 10.4322/ prmj.2017.038PRMJ

30 Frossard VC, Dias MC. O impacto da internet na interação entre pacientes: novos cenários em saúde. Interface Comun Saúde Educ. 2016;20(57):349-361. Doi: 10.1590/1807-57622014.1334

31 Edler SV. Tempos compulsivos: a busca desenfreada pelo prazer. Rio de Janeiro: Casa da Palavra; 2017

32 Novaes JV, Vilhena J. O corpo que nos possui: corporeidade e suas conexões. Curitiba: Appris; 2018 